\title{
The Development of Regional Economic Integration and China's Foreign Regional Economic Strategy
}

\author{
Xiong Yan \\ Nanchang Institute of Science and Technology, Nanchang, China
}

Keywords: economy; mode; regional economic integration; China's foreign regional economic strategy

\begin{abstract}
Regional economic integration is a natural product after the productivity has reached a certain level. China has successfully joined the tide of the foreign regional economy. This paper starts with the concept of regional economic integration, and analyzes its causes, status quo, characteristics, existing problems and future development trend, focuses on the regional economic integration in which China participates, analyzes China's foreign regional economic strategy and puts forward suggestions for future development.
\end{abstract}

\section{The Concept of Regional Economic Integration}

Regional economic integration is a manifestation of regional international economic organizations. Compared with general regional economic organizations, it is more closely related in regional economic dependence and collaboration, and there is interaction between things. Similarly, the development of regional economic integration has also greatly promoted the establishment and development of regional international economic organizations.

Specifically, regional economic integration emphasizes that international organization involving two or more countries and regions, sign agreements or treaties, mutually eliminate barriers that hinder economic and trade development and economic integration, and then carry out different levels of policy and institutional cooperation to promotes economic and trade development between each other.

In the development of regional economic integration, the following forms are mainly formed, including free trade zone (North American Free Trade Area), customs union (European Economic Community), common market (South American Common Market), economic and monetary union, political alliance. The prototype of regional economic integration first appeared in 1921, when Belgium and Luxembourg first formed an economic alliance, and later the Netherlands joined, and finally the Benelux economic alliance is formed.

\section{Main Causes of the Emergence and Development of Regional Economic Integration}

The emergence and development of a thing must be caused by a number of factors. If a certain factor is lacking, then the current form of regional economic integration will not be formed. But whether it is economic integration in developed countries, economic integration in developing countries, or mixed integration, is to protect their own interests and to develop their own economies and improve comprehensive strength while creating a good international atmosphere.

\subsection{Historical causes}

After the Second World War, social productivity and science and technology began to develop rapidly, which laid a solid and objective foundation for regional economic integration. In addition, the United Nations and some major powers actively promote free trade, implemented international economic cooperation, and established various regional economic cooperation organizations, which has directly promoted the emergence and development of regional economic integration. 


\subsection{The requirements of the times}

It is said that to learn to adapt to the trend of the times. Once there is the products that meet the requirements of social productivity, it is necessary to try. The direct cause of regional economic integration is to unite and counterbalance the powerful external forces. What kind of environmental background is there, the corresponding new things will come into being.

In addition, trade and investment liberalization has also created a source for its continuous development; and the effects are also important reasons for its endless life. For the new round of reform and development of regional economy, economic and political factors are important.

\subsection{Economic factors}

If more goods are sold to make profits, it is necessary to expand the market. Nowadays, more and more countries have learned through practice that only by choosing the market economic system can they accelerate their own development and enhance their international competitiveness to participate in international trade. After the third scientific and technological revolution, in order to achieve better development, after the reforms of various countries, the obstacles in the economic system of trade, capital, and production factors in the transaction were eliminated to promote the development of economic integration.

The World Trade Organization is an essential element in global economy. Over the years, it has promoted trade liberalization and economic globalization, but due to its own big size and complexity of procedures, there are also many drawbacks. For example, member states must continue to operate with unanimous consent, but it is not easy for everyone to agree, which has stimulated the development of regional economic integration to some extent. Countries and regions with geographical proximity, and the similar economic level, political system, and the cultural background consciously form regional economy.

\subsection{Political factor}

The most typical one is Europe. The initial cooperation is for political purposes, seeking political peace, alleviating conflicts and stabilizing the current situation.

Some developing countries will join regional economic integration as a way to promote domestic institutional reform. For example, in the 1990s, countries in transition such as Eastern Europe were in the process of promoting the transition to market economy.

Secondly, the level of development in countries participating in regional economic integration is still different, and the strengths of different economies are also different. Regional economic integration also satisfies the wishes of some countries to seek political protection at the regional level to counter other region groups.

At the same time, some countries have invisibly spread the subject politics values. For instance, after the Iraq war in May 2003, the United States offered to launch a free trade zone with some countries in the Middle East before 2003. In public opinion, it is widely believed that the real purpose of the US is to promote an American-style democracy in the region through a free trade zone.

\section{Status Quo and Characteristics of Regional Economic Integration}

\subsection{The increasing number}

After entering the 1990s, the number of regional economic integration has risen sharply. Especially since the establishment of the WTO, this trend has become more apparent. As of October 2002, a total of 255 regional trade integrations were notified to GATT/WTO.

\subsection{The expanding scope}

With the continuous improvement of productivity, the areas involved in regional economic integration have also expanded, and now it has extended to the field of service trade in the tertiary industry. As of July 1, 2002, in the regional trade integration among WTO members, 21 regional 
trade integration include categories of service trade, accounting for $12.2 \%$ of the total regional trade integration. At present, it seems that the tertiary industry will continue to grow and develop, and the scale of service economy and service trade will continue to expand, which will allow the scope of regional economic integration to develop continuously.

In addition, from the analysis of products involved in trade in goods, agricultural products that are considered to be the most sensitive object of trade liberalization are also included in the scope of free trade products. Besides, the new round of regional agreements also covers unified competition policies, intellectual property protection standards, investment liberalization, trade dispute resolution mechanisms, common environmental standards, labor standards, and even a common democratic concept.

\subsection{The emergence and development of cross-continent and cross-region economic cooperation}

Compared with the previous adjacent development model, since the 1990s, the composition of regional economic integration cooperation has undergone great changes, which is the emergence of cross-continent and cross-ocean regional cooperation organizations, which has broken the narrow geographical proximity concept. For example, Japan has successively signed free trade agreements with Mexico and Singapore. And the regional economic groups have also launched horizontal cooperation. A wide range of issues in the political and economic fields are discussed between ASEAN and the EU foreign ministers on has also been institutionalized. Members such as Morocco and Tunisia have also negotiated with the EU and established the "EU-Mediterranean Free Trade Area", becoming an EU's associated country and partner country. South Africa is actively preparing for the "Indian Ocean Economic Circle" with countries such as India, Australia and Malaysia. The North American Free Trade Area is also prone to reach an agreement with the Southern Cone Common Market to establish a free trade zone throughout the Americas from Alaska to Argentina.

\section{Existing Problems and Future Development Trend of Regional Economic Integration}

\subsection{Existing problems}

Everything is a double-edged sword, and regional economic integration is also the same, but in general, its benefits far outweigh the disadvantages. But the shortcomings cannot be ignored.

The common problems facing the countries of the world are becoming increasingly acute, which cannot be ignored, and the integrated economy has spread a small problem to the whole world, such as energy issues, trade protectionism, environmental issues, international terrorism, etc., still deteriorating and becoming a major issue affecting global development, which is even more worrying.

Secondly, the imbalance in integration has made the international economic organizations led by developed countries play a role in eroding the sovereignty of developing countries to a certain extent. In addition, multinational corporations have also played a certain role in restricting the sovereignty of developing countries.

Even so, it is still necessary to choose to join the wave of regional economic integration. If we do not follow the development of the times, we will be eliminated by the times.

\subsection{Future development trend of regional economic integration}

For constituent members, most regional economic groups adopt an increasingly "tolerant" attitude; for the content of cooperation, from simple goods to services, investment and intellectual property; for level, cooperation forms and levels have also shifted from low-level to high-level; for the number of participants, the "cross-regional" cooperation and the "multiple" regional group membership have begun to appear; for other forms of cooperation, the relationship between regional economic cooperation and the multilateral trading system has become increasingly close.

In short, regional economic integration has had many major impacts on world economic trade, regional economies and national economies of each country. In the long run, countries and regions 
should strive to join one or several regional groups to gain more opportunities for economic development and should not be isolated, which is the result of competition and a new starting point for higher levels of competition.

\section{Regional Economic Integration China Participates}

Regional economic integration is the trend of the times. Global economic cooperation has had a profound and huge impact on the world economy and international trade. Although China's foreign economic cooperation has started late, it has developed very rapidly.

Up to April 2009, China has established free trade zone involving 33 foreign countries and regions, specifically 14 trade zones, etc. of the Shanghai Cooperation Organization, the Asia-Pacific Economic Cooperation Trade Organization, the Asia-Europe Meeting, the China-ASEAN Free Trade Area, and China-India Freedom. Among them, six are under negotiation and eight have been signed. In addition, there are two free trade zones that are undergoing official joint research.

It is worth mentioning that the APEC meeting was held in China for the first time. At the meeting, with the theme of "New Century, New Challenges: Participation, Cooperation, and Promotion of Common Prosperity", respective views on promoting trade and investment liberalization in the Asia-Pacific region, and strengthening the multilateral trading system and economic and technological cooperation were expounded, and a broad consensus has been formed. On June 15, 2001, the first head meeting of the Shanghai Cooperation Organization was held in Shanghai. The purpose of the meeting was to emphasize the need to strengthen mutual trust and good-neighborliness among member states; to establish a new international political and economic order that is democratic, fair and reasonable.

Regional economic integration is the result of the internationalization of production and the promotion of scientific and technological revolution. The level of scientific and technological revolution and the development of productive forces requires us to accept regional economic integration. It also changes the supremacy in domestic affairs, diplomacy and military in the past. Now regional economic integration, with the interdependence of national economies, limits the country's economic sovereignty.

\section{China's Foreign Regional Economic Strategy}

When it comes to "foreign", what has to be mentioned is "opening up to the outside world." Any country that implements self-enclosure and shuts down the country is far from good. As a large developing country, China's development is also increasingly inseparable from the world. China must open to the outside world, which is also an objective truth that has been confirmed. In view of comprehensive consideration of China's national conditions and various factors, generally there are four models of foreign regional economic strategy.

\subsection{Strategy of ensuring equality while taking multi-level economic cooperation}

Generally speaking, regional economy is divided into three different levels. Then China should also divide this according to the actual situation. Where conditions permit, it is necessary to ensure equality while taking economic cooperation at the sub-regional, regional and global levels. For instance, WTO, World Bank and other intercontinental regional economic cooperation organizations should highlight their comprehensiveness; APEC, ASEAN and other regional economic cooperation should focus on key points; sub-regional economic cooperation such as Tumen River and Mekong River should highlight its reality, which has met the needs of China's economic development and conformed to the development trend of globalization.

Secondly, it is also necessary to highlight the key points of regional cooperation. From the current situation, China's focus is on the Asia-Pacific region. Finally, the strategy needs to be implementable. For immature carrying out regional cooperative economy in the scope of one's own capabilities, it is necessary to seek the second best to choose regional economic cooperation within a smaller scope. 


\subsection{Strategy from single core to multi-centered model}

China's foreign regional economic structure has a single core. In order to comply with the trend of the times, China is building a multi-centered model structure with Chinese characteristics while basing itself on the Asia-Pacific, to expand to the world with the core of China Mainland, Taiwan, Macao and Hong Kong to achieve the transition from a single core to a multi-centered model, and seek to establish closer economic and trade relations with as many regions and countries as possible in the world.

\subsection{Strategy of promoting the open regional economic cooperation organizations and seeking common benefits}

China has reached a "cooperation and win-win" on the economic basis of "self-centered for me", and formulates the initiative to open the market according to its own national conditions, so that it can properly protect itself and achieve a win-win situation, so that China is growing during the transition period, and then grow and develop in the competition.

\section{Suggestions on China's Further Development of Foreign Regional Economy}

\subsection{To implement the "Going out Policy” of enterprises}

In the past, although certain results have been achieved in the "Going out Policy", the relevant systems and laws and regulations are insufficient. "Going out Policy" helps to transform the growth of foreign trade as a whole and helps to explore larger investments in the future. In addition, it can also be considered that letting our country's "labor" go out.

\subsection{To take the initiative in regional integration agreement with the large market scale}

China is a country with a population of 1.3 billion, and a broad market and good development prospects, which is attractive to any country in the world. Therefore, other countries can become new entrants and larger trading partners in the Chinese market through trade creation and transfer, which will allow our country to gain more chips in the negotiations. Market capacity gives China a certain active position in negotiations, but it is necessary to grasp the scale.

\subsection{To carry out negotiations on regional integration with developed countries in appropriate time and place}

It is necessary not only to allow products and services to flow freely between countries, but also to comprehensively consider factors such as politics and diplomacy. Especially when the United States and the European Union refuse to become China's market economy status, it is necessary to open Australia as a breakthrough. But it is also necessary to focus on the timing and sign contracts with China and Europe in appropriate time.

\section{Conclusion}

Any new thing has to go through a process of constant development and change, and eventually it will become mature. Regional economic integration is the product of economic development and productivity improvement. Although China started late, with China's increasing economic level and comprehensive national strength, China will also stand in the world with a stronger image.

\section{References}

[1] Chen Tinggen. Research on Causes of the Development of Regional Economic Integration [J]. China Economist, 2006 (06).

[2] Meng Qingmin. Integrative Idea and Mechanism of Region Economy [J]. Research on Development, 2001 (02).

[3] Pan Zhuangchen, Liu Wei. Research on Development Characteristics and Strategies of China's 
Foreign Regional Economic Integration [J]. Economic Review, 2010 (07).

[4] Yang Guoliang. Relationship between Globalization of World Economy and Integration of Regional Economy [J]. Journal of Guangxi Normal University, 2004 (10).

[5] Yu Lixin, Wang Jiajia. The Choice of Strategic Patterns on China's Regional Economic Cooperation [J]. Finance \&Trade Economics, 2003 (2). 